\title{
Calcific Metamorphosis with Pathological Root Resorption in Permanent Teeth: Morphohistometric Evaluation of Two Cases
}

\author{
Metamorfosis Calcificante Asociada a Reabsorción Patológica Radicular \\ en Dientes Permanentes: Evaluación Morfohistométrica de Dos Casos
}

Gabriel M. Fonseca,*** \& Miguel M. Fonseca**

FONSECA, G. M. \& FONSECA, M. M. Calcific metamorphosis with pathological root resorption in permanent teeth: morphohistometric evaluation of two cases. Int. J. Morphol., 33(2):712-718, 2015.

SUMMARY: Calcific Metamorphosis (CM) is a pulpal response to dental trauma characterized by a deposition of hard tissue within the canal space. A tooth with CM usually presents a discoloration and a partial or total obliteration of the pulp canal space, and its vital pulp tests and symptoms are difficult. Since pulp necrosis cannot be supposed even the negative responses, the periradicular status is the only reliable criterion. Two permanent teeth diagnosed as CM and pathological root resorption, extracted from two males (22 and 53 years of age) due to severe mobility were prepared and sectioned for histological and histometrical evaluation. Images were captured, processed and measured in a total mapping of each specimen with software Pinnacle Studio 9.4® (Pinnacle Systems Inc.), Adobe ${ }^{\circledR}$ Photoshop ${ }^{\circledR}$ (CS 8.0.1, Adobe Systems Inc.) and Image J® (National Institute of Health, Bethesda, MD, USA). The images showed the simultaneous occurrence of CM and root resorption. The means of the total measurements showed that the area of radicular affection (R) was higher than the coronal affection (C), both in quantity (R: $13.75 \mathrm{~mm}^{2}-28.75 \%-/ \mathrm{C}: 4.7 \mathrm{~mm}^{2}-5.47 \%$-) and quality (R: absence of CM / C: presence of CM). CM showed a fibrotic pattern, a cortical bone-like pattern and a cancellous bone-like pattern, representing a kind of reparative reaction probably initiated by the resorption process. Concurrent $\mathrm{CM}$ and pathological root resorption are uncommon in the same tooth, and the possibility to obtain specimens of permanent teeth to make histological and histometric evaluations of them represents a situation even more infrequent. This morphohistometric evaluation can expand the spectrum of useful variables to make clinical and therapeutic odontological decisions.

KEY WORDS: Dental pulp; Calcific metamorphosis; Pathological root resorption; Diagnoses; Endodontics.

\section{INTRODUCTION}

Traumatic dental injuries can affect all the hard and soft tissues in and surrounding the teeth. Concussion, subluxation and luxation are moderate injuries in a majority of cases; they can be associated with minor symptoms and, therefore, go unnoticed both by the patient and/or by the clinician (Malhotra \& Mala, 2013; Velásquez et al., 2014). These events and their clinical management can present important challenges to the odontologist; since the sequel can arise several years after the injury, proper medical and dental history, as well as a detailed history of the dental trauma, a thorough clinical examination will assist the dental provider in formulating a proper diagnosis and subsequently, adequate treatment (Ajmera \& Mulay, 2013).

Pulpal reactions to traumatic injuries can vary from immediate pulpal necrosis to long-term response depending on the degree and type of trauma, age of the patient and the condition of the tooth in the post-traumatic period. In a pulp with moderate or very good prognosis for healing, the tooth can show an obliteration of the pulp chamber and canal in periods of 18 months to five years or more. This is a common sequel to dental trauma and it was referred as Calcific Metamorphosis (CM) also called Pulp Canal Obliteration (Malhotra \& Mala; Oginni et al., 2009). This condition is defined by the American Association of Endodontists as “...a pulpal response to trauma characterized by rapid deposition of hard tissue within the canal space" (Siddiqui, 2014).

The frequency of CM depends on the extent and severity of the injury and the stage of the root development at the time of the event, and up to $24 \%$ of traumatized teeth develops varying degrees of this condition (Malhotra

\footnotetext{
* Professor, Department of Integral Adult Dentistry, CIMA Research group, Faculty of Dentistry, Universidad de La Frontera, Temuco, Chile ** Professor, Department of Oral Pathology, Faculty of Dentistry, National University of Cordoba, Cordoba, Argentina.
} 
\& Mala). There appears to be a significant correlation between CM and a history of tooth mobility as a result of the trauma (Heling et al., 2000; Holcomb \& Gregory, 1967; Siddiqui). Although it can be recognized clinically as early as 3 months after injury, in most cases it goes undetected for about one year or more (Oginni et al.).

The clinical picture of CM has been described as a tooth with a yellowish or yellowish brown discoloration than the normal adjacent teeth because of a decrease in translucency due to a greater thickness of dentine (Ajmera \& Mulay; Manuel et al., 2010). However, not all such teeth become discolored, and there is no correlation between the amount of discoloration and the degree of CM (Holcomb \& Gregory). The radiographic appearance of $\mathrm{CM}$ is a partial (limited to the coronal part of the tooth) or total (extended to the coronal and radicular pulp canal spaces) obliteration of the pulp canal space with normal periodontal membrane space and intact lamina dura (Holan, 1998; Malhotra \& Mala). When CM is associated with apical periodontitis, a thickening of the periodontal ligament space or peri-radicular radiolucency may be observed, with or without subjective symptoms (Malhotra \& Mala).

Vital pulp tests and symptoms of CM are difficult; responses to heat and cold decrease with time and the response to electric pulp tests may be normal in the early stages but absent in the later stages. Generally there is no sensitivity to percussion. Teeth with CM may or may not have symptoms, depending on the status of pulp tissue within the mineralized canals (Holcomb \& Gregory; Malhotra \& Mala; Oginni et al.). There also seems to be no correlation between the amount of discoloration and the response to the vitalometer (Holcomb \& Gregory). Jacobsen \& Kerekes (1977) concluded that a negative respond to sensitivity tests not necessarily indicate pulp necrosis, and the periradicular status seems to be the only reliable criterion. The therapeutic significance of all these signs has been a recurrent topic in the literature. Even though some classical authors recommended the endodontic therapy, apical surgery and retrograde endodontic treatment or even the extraction due CM could represents a potential focus of infection (Patterson \& Mitchell, 1965), other authors underlined that this condition does not justify these procedures since endodontic complications (pulp necrosis and apical rarefaction) occurred in less than one-third of teeth with CM and routine endodontic therapy is virtually impossible (Holcomb \& Gregory; Jacobsen \& Kerekes; Munley \& Goodell, 2005).

Histology of CM is characterized by an abnormal deposition with characteristics of bone-like, dentine-like or fibrotic tissue with entrapment of some pulpal cells (Malhotra \& Mala; Piattelli \& Trisi, 1993; Robertson et al., 1997). Holan mentioned that the histologic appearance of this calcified tissue was different from typical irregular secondary dentine adjacent to the primary dentine in the same section, excluding the possibility that this abnormal tissue was some kind of dentine. CM is a response of a vital pulp to trauma; it was proposed that the temporary disruption of blood supply in trauma occurs followed by destruction of odontoblasts and activation of undifferentiated mesenchimal cells that form the reparative tissue (Ajmera \& Mulay). Heling et al., mentioned that $\mathrm{CM}$ might be seen as a metaplastic transformation of the pulp into bone-like tissue.

Even though the degree of obliteration, the type of tissue and their distribution in the pulp chamber, seem to be fundamental considerations to be able to make the appropriate decisions, it is not possible to determine the extent of the obliteration only from a clinical or radiographic examination (Malhotra \& Mala). It was accepted that the obliteration of the pulp canal spaces advances in a coronoapical direction, but only the histologic evaluation of the narrow pulp canals confirmed the existence of pulp tissue when the obliteration was total (Malhotra \& Mala). Robertson et al., suggested that even though different types of obliterating tissues did not correspond to clinical diagnoses, it could correspond to certain histological combinations of these types.

The pathological root resorption has numerous reports in the literature and it has been associated with a long-standing chronic inflammation in the pulp. Between the different contributory factors, trauma has been suggested as one of the primary triggers. Regardless, this condition has been classified as internal and external (with subdivisions), the devastation rate of resorption may be rapid or slow and an opportune treatment is recommended in all diagnosed cases. When root destruction makes incompatible the permanence of the teeth in the arch, extractions must be planned (Caliskan \& Türkün, 1997; Armas et al., 2008).

Concurrent $\mathrm{CM}$ and pathological root resorption are uncommon in the same tooth (Armas et al.; Kuster, 1981; Peterson et al., 1985) and the possibility to obtain specimens of permanent teeth to make histological and histometric evaluations of them represents a situation even more infrequent (Kuyk \& Walton, 1990; Piattelli \& Trisi). We present a morphohistometric evaluation of two permanent teeth where the characterization and distribution of these conditions can expand the spectrum of useful variables to make clinical and therapeutic decisions. 


\section{MATERIAL AND METHOD}

The material consisted of two permanent teeth obtained from two males (aged 22 and 53 years) referred to the Oral Pathology at the Faculty of Dentistry of the University of Cordoba (Argentina). Teeth had been exposed to trauma and extracted at different time intervals after injury. $\mathrm{CM}$ associated with pathological root resorption was diagnosed in both cases according to the almost complete obliteration of pulp chamber and the extensive root resorption radiographically (Table I). After having obtained informed consent from the patients, extractions were made due to the extensive loss of marginal bone and severe mobility.

The teeth were washed with physiological solution, fixed and stored immediately after extraction in $10 \%$ neutral-buffered formalin until sectioning. All teeth were decalcified by immersing in $7.5 \%$ nitric acid and dehydrated in ascending concentrations of ethyl alcohol and conventionally prepared for paraffin embedding, then serially sectioned to obtain 5- to $10-\mu \mathrm{m}$ slides. Sections were stained with hematoxylin and eosin for histological evaluation. All procedures were made in according with previous reports to avoid artifacts of space and staining, and to obtain a very good microscopic resolution of all of the structures (Patterson \& Mitchell; Piattelli \& Trisi).

Histological and histometric evaluations were made at the Oral Pathology Department, Laboratory of Experimental Pathology and Tissue Engineering, Dental School, University of Tucuman (Tucuman, Argentina). The more representative sections were selected evaluated with a Sony digital camera (Sony Corp., Tokyo, Japan) mounted on an Olympus CH30 light microscope (Olympus, Center Valley, PA, USA). Images were captured in horizontal and vertical sequences by using software Pinnacle Studio 9.4® (Pinnacle Systems Inc.) at magnification x 56.7. Adobe ${ }^{\circledR}$ Photoshop ${ }^{\circledR}$ software (CS 8.0.1, Adobe Systems Inc.) was used to fuse the saved images in a total mapping of each specimens and images were measured off-line using Image $\mathrm{J} \circledast$ (National Institute of Health, Bethesda, MD, USA).

\section{RESULTS}

The histologic findings showed the simultaneous occurrence of $\mathrm{CM}$ and root resorption. Although the vitality pulp tests were negative, pulps had degenerative images but no necrosis images. Whereas there was an almost complete absence of the pulp chamber in both cases with a calcified tissue occluded the pulpal lumen, an internal resorption was represented by resorption lacunae along the root canal walls without this hard tissue apposition. The histometric evaluation is represented in Figures 1 and 2. The means of the total measurements showed that the area of radicular affection $(\mathrm{R})$ was higher than the coronal affection $(\mathrm{C})$, both in quantity (R: $13.75 \mathrm{~mm}^{2}-28.75 \%$ - /C: $4.7 \mathrm{~mm}^{2}-5.47 \%-$ ) and quality (R: absence of CM / C: presence of CM).

An abnormal tissue occluding the coronal pulp demonstrated the CM. This tissue showed three different patterns, all of a collagen structure: a) a fibrotic appearance resembling collagenous connective tissue, with courses of collagen-like fibers and cells. In parts this pattern filled the resorption cavities; b) a calcified mass resembling a "cortical bone" with a concentric layer structure and numerous but empty cell lacunae. This pattern was located in the peripheral of the $\mathrm{CM}$; c) a trabecular pattern resembling a "cancellous bone", located in the most internal part of the CM and surrounding the pulp tissue; this pattern has the same concentric layer structure and lacunae and in parts resembled denticles-like or barriers-like forms. The remains of pulp showed signs of aging, atrophy and fibrosis with loss of odontoblasts. In contact with the active resorption cavities, inflammatory cells were found. The main conclusion of the histological evaluation was that the CM could represent a

Table I. Clinical characteristics and history of the samples included in the calcific metamorphosis study.

\begin{tabular}{|c|c|c|c|c|c|c|c|c|}
\hline Case \# & Age & Tooth & $\begin{array}{c}\text { Age of } \\
\text { trauma }\end{array}$ & $\begin{array}{l}\text { Type of } \\
\text { trauma }\end{array}$ & $\begin{array}{c}\text { Diagnosis } \\
\text { at trauma }\end{array}$ & Clinic image & Radiograph & $\begin{array}{l}\text { Pulp vitality } \\
\text { cold/heat tests }\end{array}$ \\
\hline 1 & 22 & 12 & 9 & $\begin{array}{l}\text { Direct } \\
\text { (Fall) }\end{array}$ & $\begin{array}{c}\text { Lateral } \\
\text { luxation }\end{array}$ & $\begin{array}{c}\text { No discoloration. } \\
\text { Asymp tomatic. Severe } \\
\text { mobility. }\end{array}$ & $\begin{array}{l}\text { Almost complete } \\
\text { obli teration of pulp } \\
\text { chamber, } \\
\text { pathological root } \\
\text { resorption. } \\
\text { Extensive loss of } \\
\text { marginal bone }\end{array}$ & Negative \\
\hline 2 & 53 & 11 & 23 & $\begin{array}{l}\text { Direct } \\
\text { (Blow) }\end{array}$ & $\begin{array}{c}\text { Lateral } \\
\text { luxation }\end{array}$ & $\begin{array}{l}\text { Yellowish discolored. } \\
\text { Asymp tomatic. Severe } \\
\text { mobility }\end{array}$ & $\begin{array}{l}\text { Almost complete } \\
\text { obli teration of pulp } \\
\text { chamber, } \\
\text { pathological root } \\
\text { resorption }\end{array}$ & Negative \\
\hline
\end{tabular}



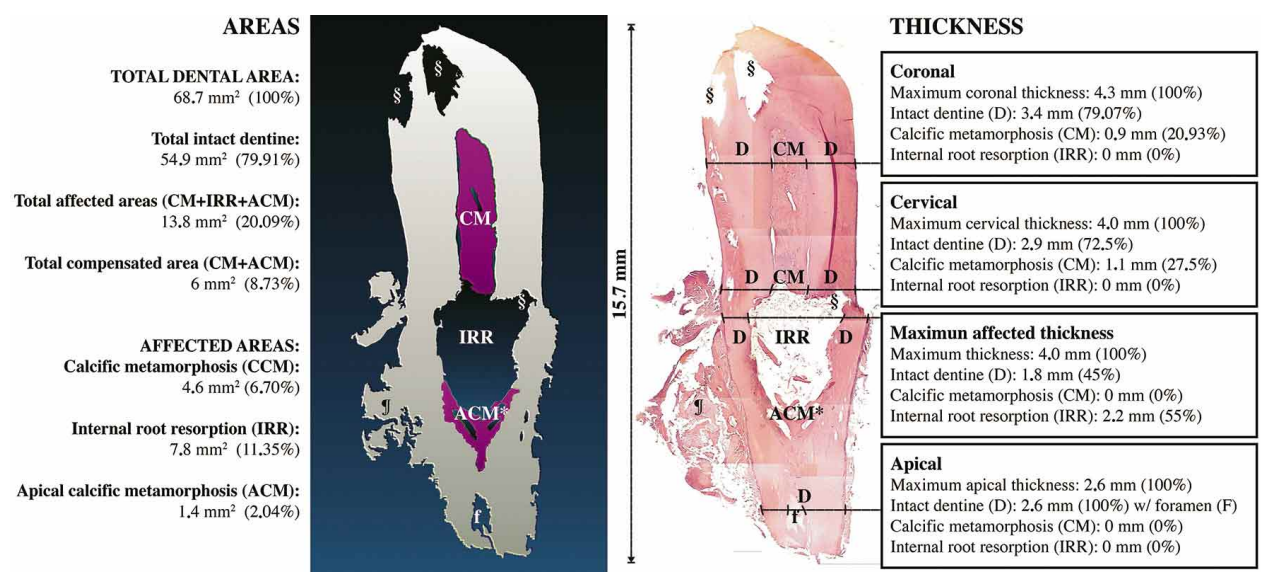

Fig. 1. Case \#1. Histometry and mapping at 56.7X. See the differences between coronal and apical areas in quantity and quality of affection and presence of abnormal tissues. CM is presented in apical of the canal space.
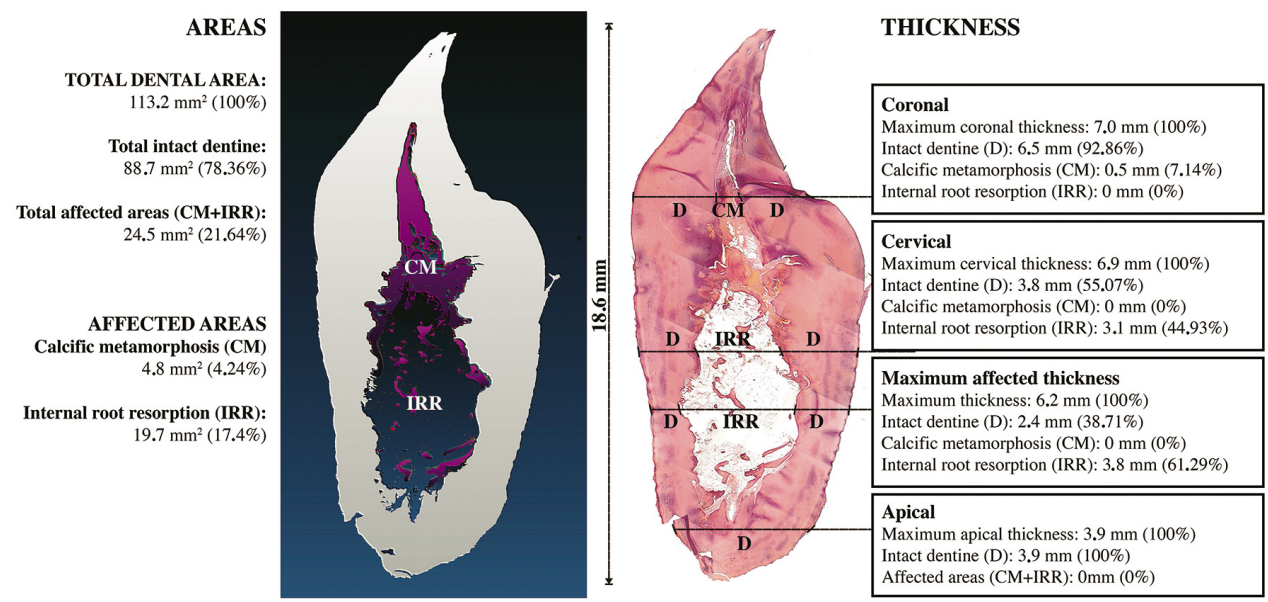

Fig. 2. Case \#2. Histometry and mapping at 56.7X. See the similar pattern as the Case \#1 with the exception of the apical CM.

reparative reaction initiated by the resorption process, and the different patterns of $\mathrm{CM}$ only represent different stages of an abnormal collagen organization and calcification (Fig. 3A-F).

\section{DISCUSSION}

$\mathrm{CM}$ is common sequelae of trauma, and most authors have considered it to be relatively benign. It does not normally affect the viability of the tooth (Peterson et al.). However, and in very rare cases, this condition can be associated to aggressive pathological root resorption making incompatible the permanence of these teeth in the arch. The evaluated specimens were detected during a clinical experience of more than 50 years together between the two authors, and the extractions were indicated due to the extensive loss of marginal bone and severe mobility of teeth. The patients were informed of all therapeutic options and they consented the invasive procedures knowing that the endodontic intervention was nonviable.

Our findings established a remarkable difference between the type of reactive tissue associated with the area of the pulp: the almost exclusive presence of CM as a compensatory tissue in the pulp coronal chamber represents a trace of a complex pulpal reaction, which has not been possible in the root area. The calcified tissue occluding the coronal pulp chamber appeared to represent a reparative response to a prior process of resorption since the normal coronal dentine have scalloped margins in contact with the abnormal tissue. The root resorption had a predominant destructive process without a reparative response (only the case \#1 showed minimal area of calcific degeneration and enlargement in the apical pulp space). The peripheral aspects of both teeth had scalloped depressions, which represent areas of external resorption.

We coincide with Robertson et al. in that the reason for the varying hard tissue responses is unclear. However, and agreeing with Peterson et al., all different patterns could be interpreted as a dynamic "reparative in nature" process; the morphological images may represent different stages of an abnormal collagen organization and calcification trying to compensate the resorted dentine. CM showed as an advance stage of this process, which can explain the fibrotic pulp and the absence of a normal pulp tissue identified by Robertson et al. Even though CM required a primary stimulation of cells by different mechanisms (including the later mineralization) (Malhotra \& Mala), our findings seem to 


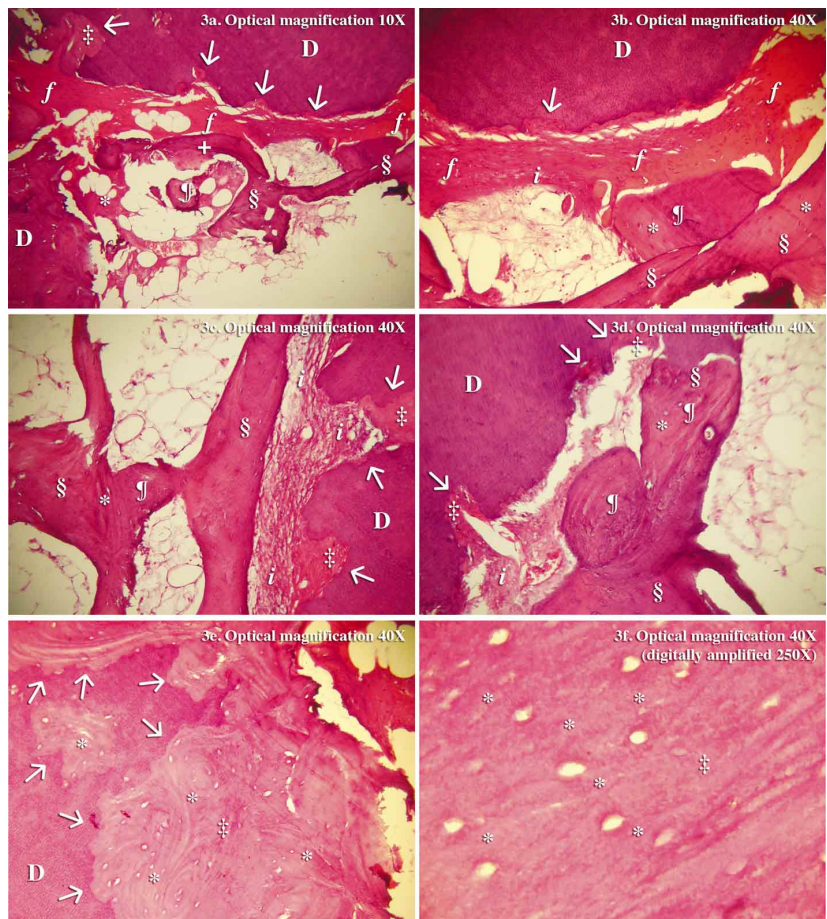

Fig. 3. Dentine (D) with resorption cavities (arrows) filled by CM with patterns of fibrosis (f) and cortical bone-like tissue (†). The fibrotic appearance has an intense inclusion of cells in parts. The cancellous bone-like tissue ( $\S)$ is represented by a trabecular pattern in the most internal part of the CM. Both cortical bone-like tissue and cancellous bone-like tissue have a concentric layer structure and numerous but empty cell lacunae (*). The cancellous bone-like tissue resembled denticles-like or barriers-like forms in parts (II). In local areas, an active chronic inflammatory reaction was detected (i).

demonstrate an "exhaustion" of the reparative resources of this process. The final stage of this reaction would be the cortical bone-like pattern or "osteodentine" named by some authors (Holan; Piattelli \& Trisi). CM is initiated by a stimulation of odontoblastic activity and the pathologic root resorption is initiated by stimulation of odontoclastic activity, but the relationship between both processes is still unclear. Kuster proposed two possibilities: the odontoblasts idiopathically will develop into odontoclasts or a new trauma will stimulate odontoclastic activity on a prior CM.

Peterson et al., reported in 1985 a case of CM in the coronal and cervical third of the root of a primary maxillary right central incisor. Concurrently, a large area of internal root resorption was evident in the middle and apical portions of the root. This tooth was extracted because of the internal resorptive activity. The histologic findings indicated the simultaneous occurrence of $\mathrm{CM}$ and internal resorption. Large areas of degeneration and enlargement were found within the pulp, with scalloping of dentine walls and loss of odontoblasts. The internal resorption was represented by resorption lacunae along the pulpal dentinal wall, occasionally with adjacent multinucleated giant cells, which represented dentinoclasts. $\mathrm{CM}$ was demonstrated by a large calcific mass that has numerous cell lacunae, most of which are empty. The authors described this calcified material as "osteodentine" and they referred that it appeared to be reparative in nature. One area at the peripheral aspect of the tooth had a scalloped depression, which could represent an area of external root resorption. We believe that the chronic nature of the response and the possibility of having more time to develop it, favored the appearance of the concentric layers resembling a cortical bone. Primary teeth do not have decades to respond in that way, and that would explain the differences with permanent teeth mentioned by Robertson et al.

The histological patterns coincide with previous references (Holan; Peterson et al.; Piattelli \& Trisi; Robertson et al.) and curiously were reported by another author in a different context. Blackwood (1959) described: “...within the pulp chamber the pulp was replaced by densely packed, elongated cells arranged with their long axes parallel with the long axis of the tooth. These cells resembled ordinary connective tissue cells or fibroblasts and were supported by a rich vascular capillary network", and added “...the odontoblast layer was absent from the pulp and instead of the normal predentine zone the pulp chamber was lined by a thick layer of calcified tissue containing numerous and irregular cell inclusions. This layer of calcified tissue was directly continuous with the primary dentine, and its matrix appeared identical with that of the dentine. The cell inclusions were irregularly distributed throughout this matrix and were contained in small lacunae with two, three or more cells frequently occupying the same lacuna. Occasionally, some fine capillaries also entered the developing matrix and were found to terminate within the lacunae among the cell inclusions". The author reported the reparative processes in relation to the fractures of two incisors removed six months after injury, and these histologic findings were interpreted as a metaplasia in the connective tissue, attributed to the very high osteogenic potentialities of fibrous repair tissue. Our findings seem to coincide with Blackwood's explanation: "... like other highly specialized tissues, the dental pulp is particularly susceptible to injury and, except under certain well-defined conditions, does not regenerate. It can, therefore, be readily appreciated that there has been an abrupt cessation of tubular dentine formation as a result of injury to the tooth, but the cellular calcified collagenous tissue which is subsequently formed by the injured pulp demands further explanation". Even though the author underlined that the examination of this abnormal tissue reveals some obvious differences with bone, cementum, or normal dentine (in fact, we coincide with these appreciations), Heling et al., after examining under scanning electron microscope an extracted premolar with $\mathrm{CM}$, they 
described a lacunar aspect of the calcified material showing typical bone morphology with osteoplasts and their canaliculi surrounded by calcified collagen fibers. The authors mentioned that the early stage of tooth development and the absence of infection are relevant factors in the development of this condition. Again, the author used the terms "regenerative change" and "metaplasia".

The histometrical evaluation in area and thickness supported the affirmation that the obliteration of the pulp canal spaces advances in a corono-apical direction (Malhotra \& Mala), not only in quality (the patterns of tissue) but also in quantity of the dentine affection. The root showed an evident expansion of the pathological resorption with an absence of pulp compensation, compared with the coronal dentine with the $\mathrm{CM}$ compensating minimal resorted areas. We cannot interpret the how-and-why of these results, but the principle "form follows function" maybe justifies more in-depth dynamics studies or even justifies the close monitoring of progress of CM when it has been diagnosed. Since the CM could represent a reparative process of a damaged pulp, the occlusal contact can act as a trigger for both repair and for resorption (Malhotra \& Mala).

The American Association of Endodontists (AAE) has designed an Endodontic Case Difficulty Assessment Form that may be used by general dentists when deciding whether to refer endodontic treatment. The conditions listed in the form are potential risk factors that may complicate treatment and adversely affect the outcome. Teeth with CM fall into the high difficulty category and achieving a predictable outcome will be challenging for even experienced practitioners (Munley \& Goodell). The practitioner is faced with the options of preventing a possibly untreatable pathological situation in the future or not treating the tooth, with the hope that no pathological sequel will arise at a later date (Ajmera \& Mulay). The question arises as to whether prophylactic root canal treatment should be initiated before the calcification process renders the canal difficult or impossible to negotiate (Oginni et al.). Stroner \& Van Cura (1984) reported a case of CM in a 36 year-old male with two asymptomatic and uninvolved maxillary incisors. No treatment was performed for 12 years and the teeth remained asymptomatic. When treatment became necessary because of crown fracture, a perforation occurred during the attempt to create a canal. Since the apparent radiographic diameter size does not always correspond to true canal size (Kuyk \& Walton), and there is no correlation between the amount of discoloration and the completeness of obliteration of the pulp chamber (Holcomb \& Gregory), our findings contribute new evidence to make available a morphological approach to this condition, where the current technologies increase the possibilities of success and facilitate minimally invasive treatments (Malhotra \& Mala).
The terms that define CM usually refers obliteration and/or deposition of hard tissue in connection with radiographic diagnosis (Siddiqui; Jacobsen \& Kerekes). Some classical authors have used the term "dystrophic calcification" (Stroner \& Van Cura), "metaplasia" (Heling et al.) and "osteodentine" (Holan; Piattelli \& Trisi). A systematic review of the literature trying to give consistency of the terminology, mentioned that the terms "Pulp Canal Obliteration" and "Calcific Metamorphosis" appear to be inaccurate because the canal is rarely completely obliterated, and there is actually no "metamorphosis" of the tooth, just a progressive deposition of dentine (secondary or tertiary) resulting in radiographically apparent shrinkage of the pulp canal space. Hence, the authors recommend the term "mineralization" to define this condition (Levin et al., 2009).

We believe that the process is more complex than a simple "mineralization" of the pulp, where a particular response of the cells results in an abnormal and reparative in nature tissue with specific characteristics and dynamics. This condition cannot be explained simply as an obliterating process or deposition of dentine. Calcific metamorphosis appears to be the more appropriate way to name this condition since both organic and inorganic compounds are present and cells show a singular adaptive functioning to make available reaction and compensation to the traumatic injury and to the loss of dentine.

ACKNOWLEDGMENTS. We really appreciate the contribution of Liliana Missana DDS, PhD for her invaluable assistance and support, and we are thankful to the Laboratory of Experimental Pathology and Tissue Engineering at the Oral Pathology Department, Dental School, University of Tucuman (Argentina).

FONSECA, G. M. \& FONSECA, M. M. Metamorfosis calcificante asociada a reabsorción patológica radicular en dientes permanentes: evaluación morfohistométrica de dos casos. Int. J. Morphol., 33(2):712718, 2015.

RESUMEN: La Metamorfosis Calcificante (MC) es una respuesta pulpar a traumatismos dentales, caracterizada por un depósito de tejido duro dentro del canal pulpar. Un diente con MC usualmente presenta un cambio en el color y una obliteración parcial o total del espacio del canal pulpar, y sus respuestas a las pruebas de vitalidad y los mismos síntomas suelen ser de difícil diagnóstico. Dado que la necrosis pulpar no puede ser supuesta aún con respuestas negativas, el estado periradicular es el único criterio diagnóstico confiable. Dos dientes permanentes de dos pacientes masculinos (de 22 y 53 años) diagnosticados con MC asociada a reabsorción patológica de la raíz, extraídos por movilidad severa fueron preparados y seccionados para evaluación histológica e histométrica. Las imágenes fueron capturadas, procesadas y medidas en un mapeo total para cada espécimen utilizando software Pinnacle Studio 9.4® (Pinnacle Systems Inc.), Adobe ${ }^{\circledR}$ Photoshop ${ }^{\circledR}$ (CS 8.0.1, Adobe Systems Inc.) e Image J® (National 
Institute of Health, Bethesda, MD, USA). Las imágenes demostraron la concurrencia de MC y reabsorción radicular. Las medias de las mediciones totales expusieron que la superficie de afección radicular $(\mathrm{R})$ fue mayor que la de afección coronaria (C), tanto en cantidad (R: 13,75 $\mathrm{mm}^{2}-28,75 \%-/ \mathrm{C}: 4,7 \mathrm{~mm}^{2}-5,47 \%$-) como en calidad and ( $\mathrm{R}$ : ausencia de MC / C: presencia de MC). La MC mostró patrones de fibrosis, de tejido similar a un hueso cortical y a un hueso esponjoso, representando una forma de reacción reparativa iniciada probablemente en el proceso de reabsorción. La concurrencia entre MC y reabsorción patológica radicular es rara en el mismo diente, y la posibilidad de obtener especímenes de dientes permanentes para evaluarlos histológica e histométricamente es aún menos frecuente. Esta evaluación histométrica permitiría expandir el espectro de variables útiles para la toma de decisiones clínicas y terapéuticas odontológicas.

PALABRAS CLAVE: Pulpa dental; Metamorfosis calcificante; Reabsorción patológica radicular; Diagnóstico; Endodoncia.

\section{REFERENCES}

Ajmera, K. \& Mulay, S. Multimodality esthetic management - A case report. Int. J. Sci. Res., 4(1):1176-80, 2013.

Armas, J. M.; Savarrio, L. \& Brocklebank, L. M. External apical root resorption: two case reports. Int. Endod. J., 41(11):997-1004, 2008.

Blackwood, H. J. Tissue repair in intra-alveolar root fractures. Oral Surg. Oral Med. Oral Pathol., 12(3):360-70, 1959.

Caliskan, M. K. \& Türkün, M. Prognosis of permanent teeth with internal resorption: a clinical review. Endod. Dent. Traumatol., 13(2):7581, 1997.

Heling, I.; Slutzky-Goldberg, I.; Lustmann, J.; Ehrlich, Y. \& Becker, A. Bone-like tissue growth in the root canal of immature permanent teeth after traumatic injuries. Endod. Dent. Traumatol., 16(6):298303,2000

Holan, G. Tube-like mineralization in the dental pulp of traumatized primary incisors. Endod. Dent. Traumatol., 14(6):279-84, 1998.

Holcomb, J. B. \& Gregory, W. B. Jr. Calcific metamorphosis of the pulp: its incidence and treatment. Oral Surg. Oral Med. Oral Pathol., 24(6):825-30, 1967.

Jacobsen, I. \& Kerekes, K. Long-term prognosis of traumatized permanent anterior teeth showing calcifying processes in the pulp cavity. Scand. J. Dent. Res., 85(7):588-98, 1977.

Kuster, C. G. Calcific metamorphosis/internal resorption: a case report. Pediatr. Dent., 3(3):274-5, 1981.

Kuyk, J. K. \& Walton, R. E. Comparison of the radiographic appearance of root canal size to its actual diameter. J. Endod., 16(11):528-33, 1990.

Levin, L. G.; Law, A. S.; Holland, G. R.; Abbott, P. V. \& Roda, R. S. Identify and define all diagnostic terms for pulpal health and disease states. J. Endod., 35(12):1645-57, 2009.

Malhotra, N. \& Mala, K. Calcific metamorphosis. Literature review and clinical strategies. Dent. Update, 40(1):48-50, 53-4, 57-8 passim, 2013.

Manuel, S. T.; Abhishek, P. \& Kundabala, M. Etiology of tooth discoloration - a review. Nig. Dent. J., 18(2):56-63, 2010.

Munley, P. J. \& Goodell, G. G. Calcific metamorphosis. Clin. Update, 27(4), 2005.

Oginni, A. O.; Adekoya-Sofowora, C. A. \& Kolawole, K. A. Evaluation of radiographs, clinical signs and symptoms associated with pulp canal obliteration: an aid to treatment decision. Dent. Traumatol., 25(6):620-5, 2009.

Patterson, S. S. \& Mitchell, D. F. Calcific metamorphosis of the dental pulp. Oral Surg. Oral Med. Oral Pathol., 20(1):94-101, 1965.

Peterson, D. S.; Taylor, M. H. \& Marley, J. F. Calcific metamorphosis with internal resorption. Oral Surg. Oral Med. Oral Pathol.,60(2):231-3, 1985.

Piattelli, A. \& Trisi, P. Pulp obliteration: a histological study. J. Endod., 19(5):252-4, 1993.

Robertson, A.; Lundgren, T.; Andreasen, J. O.; Dietz, W.; Hoyer, I. \& Norén, J. G. Pulp calcifications in traumatized primary incisors. A morphological and inductive analysis study. Eur. J. Oral Sci., 105(3):196-206, 1997.

Siddiqui, S. H. Management of pulp canal obliteration using the Modified-Tip instrument technique. Int. J. Health Sci. (Qassim), 8(4):426-8, 2014.

Stroner, W. F. \& Van Cura, J. E. Pulpal dystrophic calcification. J. Endod., 10(5):202-4, 1984.

Velásquez, F.; Mancilla, C.; Niño, A. Y.; Tirreau, V.; Cortés-Araya, J.; Rojas, M. C.; Escobar, E.; Reyes-Court, D.; Calleja, S.; UlloaMarín, C. \& Sung-Hsieh, H. H. Epidemiological patterns of traumatic dental injuries (GES disease) in adult patients treated at a Chilean National Trauma Center during 2 periods. Int. J. Odontostomat., 8(2):191-9, 2014.

Correspondence to:

Gabriel M. Fonseca, D.D.S., Ph.D.

Facultad de Odontología

Universidad de La Frontera

Avenida Francisco Salazar 01145

Temuco

CHILE

Email: gabriel.fonseca@ufrontera.cl 